\title{
VERMICOMPOST INFLUENCES PROCESSING QUALITY OF POTATO TUBERS
}

\author{
J. Ferdous ${ }^{1}$, T.S. Roy $^{2}$, R. Chakraborty ${ }^{2}$, M. Mostofa ${ }^{1 *}$, R. Noor ${ }^{2}$, F. Nowroz ${ }^{2}$ \\ and B.C. Kundu ${ }^{3}$ \\ ${ }^{1}$ Institute of Seed Technology, Sher-e-Bangla Agricultural University \\ Dhaka-1207, Bangladesh \\ ${ }^{2}$ Department of Agronomy, Faculty of Agriculture, Sher-e-Bangla Agricultural University, \\ Dhaka-1207, Bangladesh \\ ${ }^{3}$ Bangladesh Agricultural Research Institute, Tuber Crops Research Centre \\ Gazipur-1701, Bangladesh
}

\begin{abstract}
The effect of vermicompost on dry matter and specific gravity of potato tubers under ambient storage condition was studied. Vermicompost was used at four rates viz. $0,2,4$ and $6 \mathrm{t} \mathrm{ha}^{-1}$ over the four varieties of potato viz. BARI TPS-1, BARI Alu-28 (Lady Rosetta), BARI Alu-25 (Asterix) and BARI Alu-29 (Courage). Results demonstrated that processing parameters such as dry matter percentage (\%) and specific gravity increased with increasing vermicompost levels while they decreased with the increasing storing period. Lady Rosetta and Asterix potato varieties can be safely stored at normal room temperature up to 60 days. There was no interaction between vermicompost rates and crop varieties. Hence, the potato growers of Bangladesh can use vermicompost at $6 \mathrm{t}$ $\mathrm{ha}^{-1}$ for achieving better yield without affecting processing quality.
\end{abstract}

Keywords: Dry matter, Potato, Specific gravity, Vermicompost

\section{INTRODUCTION}

Potato (Solanum tuberosum L.) belongs to the Solanaceae family is grown in nearly 150 countries and is the world's single most important tuber crop with a vital role in the global food system and food security (Singh 2010). It is the fourth world crop after wheat, rice and maize. The total world potato production was estimated 376.83 million Mt in 2016 (FAOSTAT 2017). In the world's top 10 potato producing countries, Bangladesh ranks $7^{\text {th }}$ position (FAOSTAT 2017). In Bangladesh, it ranks $2^{\text {nd }}$ after rice in production. The total area under potato crops, per ha yield and total production in Bangladesh were 499,725 hectares, $22.53 \mathrm{t} \mathrm{ha}^{-1}$ and 10,215,957 metric

*Corresponding author: marufsau@ hotmail.com 
ton, respectively during fiscal year 2017-18 (FAOSTAT 2017). The total production is increasing day by day because of an alternative food crop against rice and wheat and also a nutrient-rich crop that rapidly increases consumption in Bangladesh (BBS 2013).

Due to the increasing demand of consumers and foreign importers on this important crop, special attention should be given to increase its yield and quality. The storage limitation is also a serious problem in Bangladesh. Storage conditions in potato make several differences in the physiochemical properties of the tubers and textures. Potato is a perishable commodity and three variables determine storage losses in potatoes: quality of the tuber at the beginning of the storage, storage conditions, and duration of storage (Burton et al., 1992).

Storage losses are often specified as weight losses and losses in the quality of potatoes which are caused by respiration (Basker 1975); sprouting (Amoros et al., 2000); evaporation of water from the tubers (Kabira and Lemaga, 2006); changes in chemical composition and physical properties of the tuber (Cronk et al., 1974; Maga and Fitzpatrick, 1980) and damage by extreme temperatures (Linnemann et al., 1985). Nowadays, gradual deficiencies in soil organic matter and reduced yield of crop and quality are alarming problems in Bangladesh. The cost of inorganic fertilizers is very high. On the other hand, the organic manure is easily available to the farmers and its cost is low compared to that of inorganic fertilizers. Vermicompost (organic manure) is a good source of different macro and micronutrients particularly $\mathrm{N}, \mathrm{P}, \mathrm{K}$ and $\mathrm{S}$. The increased microbial activity improves the availability of soil phosphorous and nitrogen. Vermiculture is the science of rearing of earthworms for mass propagation on organic wastes under semi-natural conditions and vermicomposting is the bioconversion of organic waste materials through earthwormic ways (Senapati, 1992). Senesi et al. (1996) mentioned that vermicomposting is a controlled, aerobic, biological process and able to convert biodegradable humus like organic substances and suitable for the application of soil amendment.

Sometimes potato produced in Bangladesh is not good quality enough in respect of dry matter and specific gravity which are not present at optimum level in produced products (Keijbets, 2008). So, using different amounts of vermicompost materials may contribute for improving the quality of potato in Bangladesh's condition. The objective of this experiment was to find out the influence of vermicompost as soil supplement on processing quality of potato during ambient storage condition.

\section{MATERIALS AND METHODS}

\section{Research Location}

The research was conducted at the Agronomy Research Field of Sher-e-Bangla Agricultural University, Dhaka-1207, Bangladesh during the period from November 1, 2016 to April 30, 2017. Top soil was silty clay in texture, olive-gray with common 
fine to medium distinct dark yellowish-brown mottles. Soil pH was 5.6 and had organic carbon $0.45 \%$. The selected plot was medium high land. Plenty of sunshine and moderately low temperature prevails during experimental period, which is suitable for potato growing in Bangladesh. The weather data during the study period are presented in Table 1.

Table 1. Monthly meteorological information during the period from November 2016 to April 2017

\begin{tabular}{clccc|c|c}
\hline Year & \multirow{2}{*}{ Month } & \multicolumn{2}{|c|}{ Air temperature $\left({ }^{\circ} \mathrm{C}\right)$} & \multirow{2}{*}{$\begin{array}{c}\text { Relative } \\
\text { humidity }(\%)\end{array}$} & $\begin{array}{c}\text { Total rainfall } \\
(\mathrm{mm})\end{array}$ \\
\cline { 3 - 4 } & & Maximum & Minimum & & \\
\hline \multirow{2}{*}{$2016-$} & November & 28.10 & 11.83 & 58.18 & 47 \\
2017 & December & 25.00 & 9.46 & 69.53 & 0 \\
& January & 23.98 & 10.47 & 73.86 & Trace \\
& February & 26.45 & 14.83 & 75.38 & Trace \\
& March & 30.45 & 18.36 & 69.44 & 59 \\
& April & 35.93 & 42.35 & 73.92 & 103 \\
\hline
\end{tabular}

Source: Metrological Centre, Climate Division, Agargaon, Dhaka

\section{Experimental Design}

The experiment consisted of two factors. Factor A: Potato varieties $\left(\mathrm{V}_{1-4}\right)-\mathrm{V}_{1}$ : BARI TPS-1, $\mathrm{V}_{2}$ :BARI Alu-28 (Lady Rosetta), $\mathrm{V}_{3}$ : BARI Alu-25 (Asterix), $\mathrm{V}_{4}$ :BARI Alu29 (Courage); Factor B: Vermicompost levels $\left(\mathrm{M}_{1-4}\right)-\mathrm{M}_{1}: 0 \mathrm{t} \mathrm{ha}^{-1}$ (control), $\mathrm{M}_{2}: 2 \mathrm{t}$ $\mathrm{ha}^{-1}, \mathrm{M}_{3}: 4 \mathrm{t} \mathrm{ha}^{-1}, \mathrm{M}_{4}: 6 \mathrm{t} \mathrm{ha}^{-1}$. Experiment was provoked in a split-plot design with three replications. The variety was assigned to main plot and vermicompost to subplot. The distance between row to row was $50 \mathrm{~cm}$, plant to plant was $25 \mathrm{~cm}$ and plot to plot was $75 \mathrm{~cm}$. The size of the unit plot was $2 \mathrm{~m} \times 2.5 \mathrm{~m}$.

\section{Crop Management}

Collected all varieties of seed potatoes were certified seed and the individual weight of seed potato was 60-70 g. The experimental soil was fertilized with Urea ( $250 \mathrm{~kg}$ $\left.\mathrm{ha}^{-1}\right)$, Triple Super Phosphate (150 kg ha $\left.{ }^{-1}\right)$, Muriate of Potash $\left(250 \mathrm{~kg} \mathrm{ha}^{-1}\right)$, Gypsum $\left(120 \mathrm{~kg} \mathrm{ha}^{-1}\right)$, Zinc Sulphate $\left(10 \mathrm{~kg} \mathrm{ha}^{-1}\right)$ and Boric Acid $\left(10 \mathrm{~kg} \mathrm{ha}^{-1}\right)$ as recommended by Mondal et al., (2011). The total amount of vermicompost was applied at 7 days before planting as per treatment. The well sprouted healthy and uniform sized potato tubers were planted according to $4-5 \mathrm{~cm}$ depth in soil. Different intercultural operations such as irrigation, weeding, mulching, earthing up and plant protection measures were done as per when needed. Haulm cutting was done at 85 DAP, when 40-50\% plants showed senescence and the tops started drying. After haulm cutting the tubers were kept under the soil for 10 days for skin hardening. The potatoes of each plot were separately harvested, bagged and tagged and brought to the 
laboratory.

\section{Recording of Data}

The following data were collected during the experiment from the laboratory where the potatoes were stored with a well ventilation facility.

\section{Dry Matter Content (\%)}

The samples of tuber were collected from each treatment. After peeling off the tubers the samples were dried in an oven at $72^{\circ} \mathrm{C}$ for 72 hours. Dry matter content was calculated as the ratio between dry and fresh weight and expressed as a percentage (Barton, 1989).

\section{Specific Gravity $\left(\mathrm{g} \mathrm{cm}^{-3}\right)$}

It was measured by using the following formula -

\section{Specific gravity $=$ \\ Statistical Data Analysis}

Weight of tuber in air $(\mathrm{g})$

The data obtained for different characters were statistically analyzed following the analysis of variance (ANOVA) techniques by using Statistix 10 (2013) computer package program. The significant differences among the treatment means were compared by Least Significant Difference (LSD) at 5\% level of probability (Gomez and Gomez 1984). The correlation was calculated on the basis of data from 0 days of storage, i.e. at harvesting day. The correlation graph was plotted with the help of Microsoft Excel 2016.

\section{RESULT AND DISCUSSION}

\section{Dry Matter Content}

Significant variation was found among different varieties to dry matter content of tuber at different ambient storage time. The maximum dry matter content of tuber was shown by $\mathrm{V}_{3}(23.54 \%, 22.91 \%, 22.15 \%, 21.70 \%)$ and minimum was shown by $\mathrm{V}_{1}(19.56 \%, 18.66 \%, 17.67 \%, 17.05 \%)$ at $0,20,40$ and 60 DAS respectively (Fig. 1).

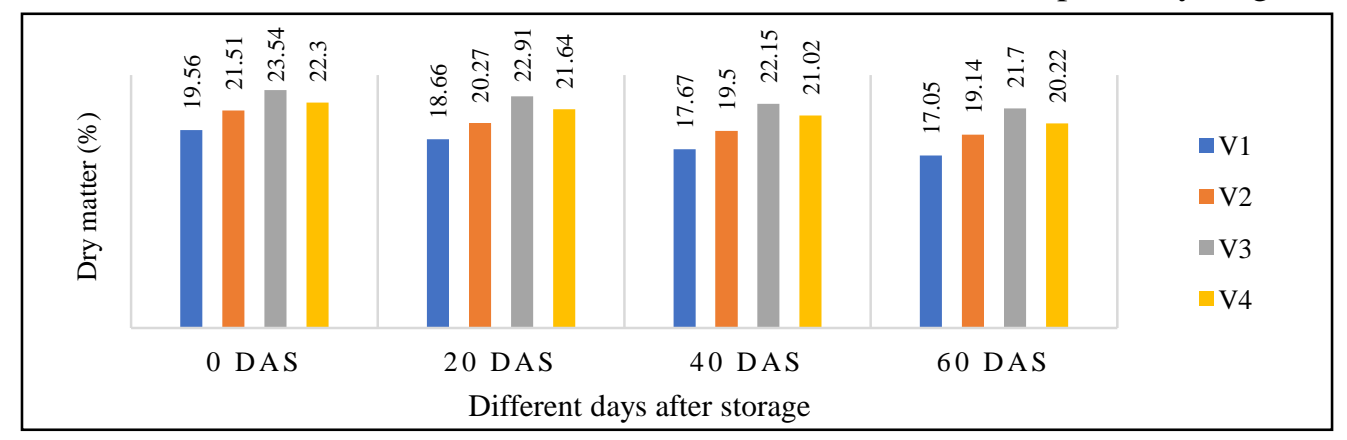

Figure 1. Effect of variety to dry matter content $(\%)$ of potato tuber at different days after storage $\mathrm{V}_{1}-$ 
BARI TPS-1, $\mathrm{V}_{2}$ - Lady Rosetta, $\mathrm{V}_{3}$ - Asterix, $\mathrm{V}_{4}$ - Courage. (LSD values 0.460, 0.694, 0.803 and 0.889 for 0 DAS, 20 DAS, 40 DAS and 60 DAS, respectively)

Profound variation was found among different levels of vermicompost on tuber dry matter content at different ambient storage time. At 0 and 20 DAS the maximum dry matter content of tuber was found by $\mathrm{M}_{4}(24.19 \%, 22.99 \%)$ and minimum was found by $\mathrm{M}_{1}(19.30 \%, 18.37 \%)$ respectively. At 40 DAS the maximum dry matter content of tuber was found by $\mathrm{M}_{4}(21.78 \%)$ which was statistically similar to $\mathrm{M}_{3}$ and minimum was found by $\mathrm{M}_{1}(17.90 \%)$. At 60 DAS the maximum dry matter content of tuber was found by $\mathrm{M}_{4}(21.40 \%)$ and minimum was found by $\mathrm{M}_{1}(17.20 \%)$ (Fig. 2).

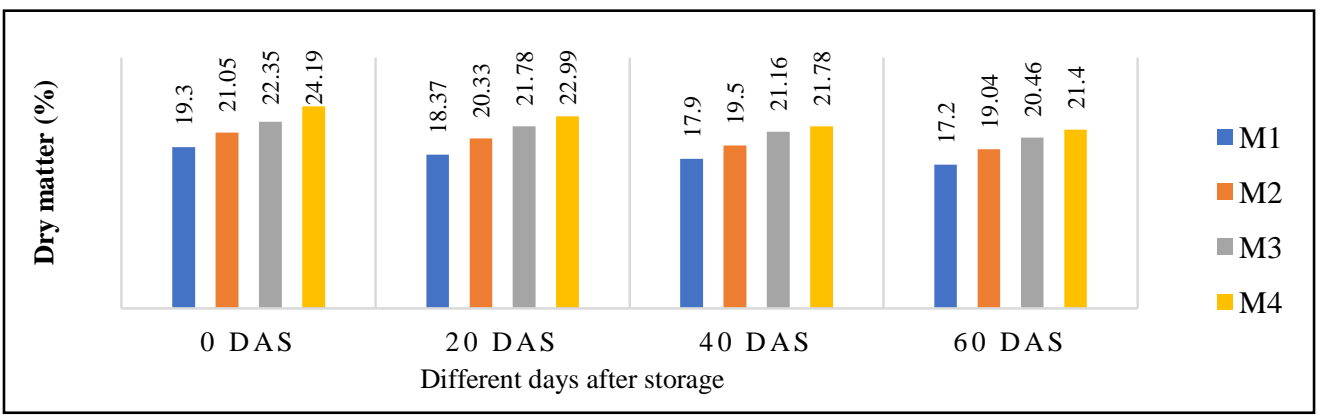

Figure 2. Effect of vermicompost on dry matter $(\%)$ of potato tuber at different days after storage $M_{1}-$ Control, $M_{2}-2 t_{t ~ h a}{ }^{-1}, M_{3}-4 t / h a, M_{4}-6 t^{t} h^{-1}$. (LSD values $0.782,0.744,0.710$ and 0.739 for 0 DAS, 20 DAS, 40 DAS and 60 DAS, respectively)

Remarkable variation was found among different variety and vermicompost levels on tuber dry matter content at different storage times. At 0 DAS maximum dry matter content was retained by $\mathrm{V}_{3} \mathrm{M}_{4}(25.13 \%)$ which was statistically similar to $\mathrm{V}_{2} \mathrm{M}_{4}$, $\mathrm{V}_{3} \mathrm{M}_{2}, \mathrm{~V}_{3} \mathrm{M}_{3}, \mathrm{~V}_{4} \mathrm{M}_{3}$ and $\mathrm{V}_{4} \mathrm{M}_{4}$; minimum was retained by $\mathrm{V}_{1} \mathrm{M}_{1}(18.39 \%)$ which was statistically similar to $\mathrm{V}_{1} \mathrm{M}_{2}$ and $\mathrm{V}_{2} \mathrm{M}_{1}$. At 20 DAS maximum dry matter content was retained by $\mathrm{V}_{4} \mathrm{M}_{4}(24.22 \%)$ which was statistically similar to $\mathrm{V}_{2} \mathrm{M}_{4}, \mathrm{~V}_{3} \mathrm{M}_{2}, \mathrm{~V}_{3} \mathrm{M}_{3}$, $\mathrm{V}_{3} \mathrm{M}_{4}$ and $\mathrm{V}_{4} \mathrm{M}_{3}$; minimum was retained byV $\mathrm{M}_{1}$ (16.94\%). At 40 DAS maximum dry matter content was retained by $_{4} \mathrm{M}_{4}(24.12 \%)$ which was statistically similar to $\mathrm{V}_{3} \mathrm{M}_{3}$ and $\mathrm{V}_{4} \mathrm{M}_{3}$; minimum was retained by $\mathrm{V}_{1} \mathrm{M}_{1}(16.44 \%)$. At 60 DAS maximum dry matter content was retained by $\mathrm{V}_{4} \mathrm{M}_{4}(23.25 \%)$ which was statistically similar to $\mathrm{V}_{3} \mathrm{M}_{3}$ and $\mathrm{V}_{3} \mathrm{M}_{4}$; minimum was retained by $\mathrm{V}_{1} \mathrm{M}_{1}(15.22 \%)$ (Table 2). 
Table 2. Combined effect of variety and vermicompost level on percent dry matter content at different days after storage of potato tuber

\begin{tabular}{c|c|c|c|c}
\hline \multirow{2}{*}{ Combination } & \multicolumn{4}{|c}{ Dry matter (\%) } \\
\cline { 2 - 5 } & 0 DAS & 20 DAS & $40 \mathrm{DAS}$ & $60 \mathrm{DAS}$ \\
\hline $\mathrm{V}_{1} \mathrm{M}_{1}$ & $18.39 \mathrm{f}$ & $16.94 \mathrm{e}$ & $16.44 \mathrm{i}$ & $15.22 \mathrm{i}$ \\
$\mathrm{V}_{1} \mathrm{M}_{2}$ & $18.57 \mathrm{f}$ & $18.14 \mathrm{c}-\mathrm{e}$ & $17.54 \mathrm{~g}-\mathrm{i}$ & $17.0 \mathrm{gh}$ \\
$\mathrm{V}_{1} \mathrm{M}_{3}$ & $19.12 \mathrm{ef}$ & $18.63 \mathrm{~cd}$ & $18.13 \mathrm{gh}$ & $17.89 \mathrm{fg}$ \\
$\mathrm{V}_{1} \mathrm{M}_{4}$ & $22.14 \mathrm{~b}-\mathrm{d}$ & $20.93 \mathrm{~b}$ & $18.57 \mathrm{fg}$ & $18.07 \mathrm{fg}$ \\
$\mathrm{V}_{2} \mathrm{M}_{1}$ & $18.82 \mathrm{f}$ & $17.56 \mathrm{de}$ & $16.86 \mathrm{hi}$ & $16.16 \mathrm{hi}$ \\
$\mathrm{V}_{2} \mathrm{M}_{2}$ & $19.79 \mathrm{ef}$ & $19.67 \mathrm{bc}$ & $18.88 \mathrm{fg}$ & $18.38 \mathrm{fg}$ \\
$\mathrm{V}_{2} \mathrm{M}_{3}$ & $22.46 \mathrm{bc}$ & $20.99 \mathrm{~b}$ & $20.57 \mathrm{de}$ & $20.41 \mathrm{de}$ \\
$\mathrm{V}_{2} \mathrm{M}_{4}$ & $24.96 \mathrm{a}$ & $22.88 \mathrm{a}$ & $21.68 \mathrm{~cd}$ & $21.59 \mathrm{~b}-\mathrm{d}$ \\
$\mathrm{V}_{3} \mathrm{M}_{1}$ & $20.57 \mathrm{de}$ & $20.54 \mathrm{~b}$ & $20.46 \mathrm{de}$ & $20.19 \mathrm{de}$ \\
$\mathrm{V}_{3} \mathrm{M}_{2}$ & $24.23 \mathrm{a}$ & $23.01 \mathrm{a}$ & $21.70 \mathrm{~cd}$ & $21.41 \mathrm{~b}-\mathrm{d}$ \\
$\mathrm{V}_{3} \mathrm{M}_{3}$ & $24.23 \mathrm{a}$ & $24.12 \mathrm{a}$ & $23.67 \mathrm{ab}$ & $22.49 \mathrm{a}-\mathrm{c}$ \\
$\mathrm{V}_{3} \mathrm{M}_{4}$ & $25.13 \mathrm{a}$ & $23.95 \mathrm{a}$ & $22.76 \mathrm{a}-\mathrm{c}$ & $22.70 \mathrm{ab}$ \\
$\mathrm{V}_{4} \mathrm{M}_{1}$ & $19.42 \mathrm{ef}$ & $18.44 \mathrm{c}-\mathrm{e}$ & $17.83 \mathrm{~g}-\mathrm{i}$ & $17.23 \mathrm{gh}$ \\
$\mathrm{V}_{4} \mathrm{M}_{2}$ & $21.62 \mathrm{~cd}$ & $20.49 \mathrm{~b}$ & $19.88 \mathrm{ef}$ & $19.35 \mathrm{ef}$ \\
$\mathrm{V}_{4} \mathrm{M}_{3}$ & $23.59 \mathrm{ab}$ & $23.40 \mathrm{a}$ & $22.26 \mathrm{bc}$ & $21.06 \mathrm{~cd}$ \\
$\mathrm{~V}_{4} \mathrm{M}_{4}$ & $24.55 \mathrm{a}$ & $24.22 \mathrm{a}$ & $24.12 \mathrm{a}$ & $23.25 \mathrm{a}$ \\
$\mathrm{CV}(\%)$ & 4.29 & 4.23 & 4.20 & 4.50 \\
LSD $_{0.05}$ & 1.57 & 1.48 & 1.42 & 1.47 \\
Level of $_{\text {significance }}$ & $* *$ & $* *$ & $* *$ & $*$ \\
\hline
\end{tabular}

Numbers in columns followed by the same letter are not statistically different at $\mathrm{P}_{0.05}$.

$* *=$ Significant at $1 \%$ level of probability. $\mathrm{V}_{1}-\mathrm{BARI}$ TPS $-1, \mathrm{~V}_{2}-$ Lady Rosetta, $\mathrm{V}_{3}-$ Asterix, $\mathrm{V}_{4}-$ Courage; $\mathrm{M}_{1}-0 \mathrm{tha} \mathrm{h}^{-1}$ (Control), $\mathrm{M}_{2}-2 \mathrm{tha} \mathrm{h}^{-1}, \mathrm{M}_{3}-4 \mathrm{tha}^{-1}, \mathrm{M}_{4}-6 \mathrm{tha}^{-1}$

Maximum dry matter content was found at the harvesting time and decreased with the increase of storage time. Among the four varieties Asterix was shown the maximum dry matter content and BARI TPS-1 was shown minimum dry matter content. The variation in dry matter content among the potato varieties were also observed by Suyre et al. (1975) and Capezio (1987). Variation in tuber dry matter content may be attributed to cultivars inherent in the production of total solids. Burton et al., (1992) reported that genetic differences among varieties a role in their ability to produce high solids when grown on the same test plot. Dry matter content is subjected to the influence of both the environment and genotypes (Miller et al., 1975; 
Tai and Coleman, 1999). There was a significant decrease in dry matter concentration through time and cultivars with high dry matter concentration at harvest could be stored for extended periods at ambient temperature without significant quality. Loss of tuber dry matter during storage period may be due to respiration (Burton et al., 1992). Sprouting is a physiological process at which resting buds break their dormancy and resume growth by utilizing stored food (Salisbury and Ross 1992). Dry matter content increased with the increasing of Vermicompost levels (Kmet'ová et al., 2013; Agrawal et al., 2017). A positive correlation $(\mathrm{r}=0.751)$ was found between the dry matter content and specific gravity of potato tuber (Fig. 3) (Mostofa et al., 2019).

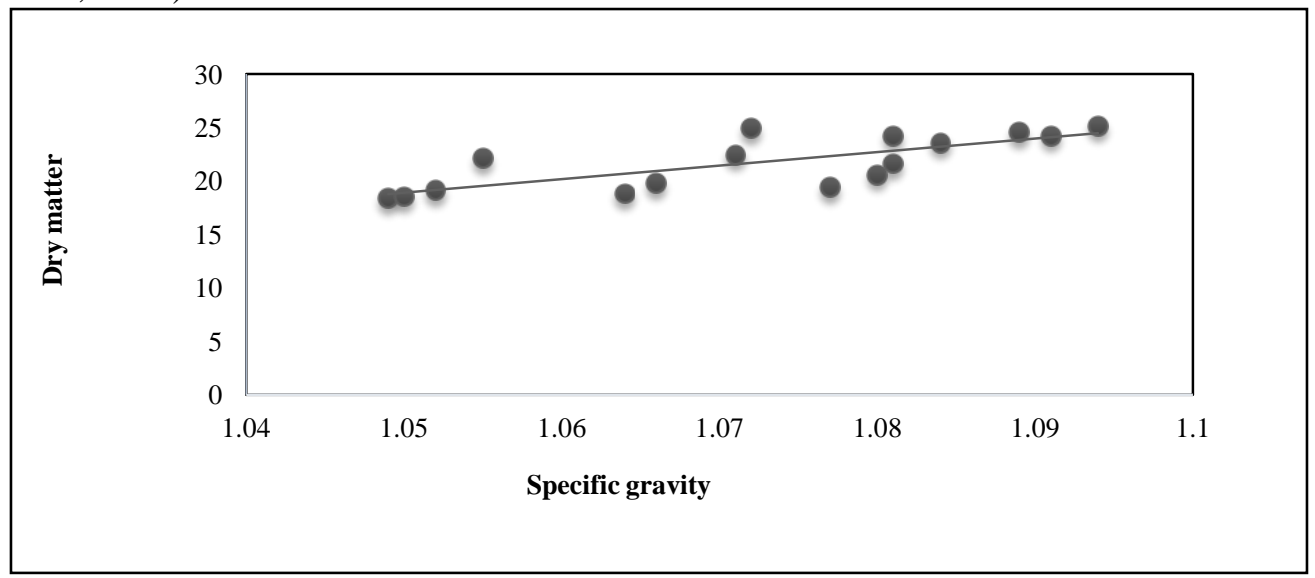

Figure 3. Relationship between dry matter content and specific gravity of potato tuber

\section{Specific Gravity}

Profound variation was found among different varieties to specific gravity of tuber at different ambient storage time. The highest specific gravity of tuber was exhibited by $\mathrm{V}_{3}\left(1.087 \mathrm{~g} \mathrm{~cm}^{-3}, 1.083 \mathrm{~g} \mathrm{~cm}^{-3}, 1.080 \mathrm{~g} \mathrm{~cm}^{-3}, 1.077 \mathrm{~g} \mathrm{~cm}^{-3}\right)$ and lowest was exhibited by $\mathrm{V}_{1}\left(1.052 \mathrm{~g} \mathrm{~cm}^{-3}, 1.045 \mathrm{~g} \mathrm{~cm}^{-3}, 1.043 \mathrm{~g} \mathrm{~cm}^{-3}, 1.037 \mathrm{~g} \mathrm{~cm}^{-3}\right)$ at $0,20,40$ and 60 DAS respectively (Table 3 ). 
Table 3. Effect of variety to specific gravity at different days after storage of potato tuber

\begin{tabular}{c|c|c|c|c}
\hline \multirow{2}{*}{ Variety } & \multicolumn{4}{|c}{ Specific gravity $\left(\mathrm{g} \mathrm{cm}^{-3}\right)$} \\
\cline { 2 - 5 } & 0DAS & $20 \mathrm{DAS}$ & $40 \mathrm{DAS}$ & $60 \mathrm{DAS}$ \\
\hline $\mathrm{V}_{1}$ & $1.05 \mathrm{c}$ & $1.04 \mathrm{~d}$ & $1.04 \mathrm{~d}$ & $1.03 \mathrm{c}$ \\
$\mathrm{V}_{2}$ & $1.06 \mathrm{~b}$ & $1.06 \mathrm{c}$ & $1.06 \mathrm{c}$ & $1.06 \mathrm{~b}$ \\
$\mathrm{~V}_{3}$ & $1.08 \mathrm{a}$ & $1.08 \mathrm{a}$ & $1.08 \mathrm{a}$ & $1.07 \mathrm{a}$ \\
$\mathrm{V}_{4}$ & $1.08 \mathrm{a}$ & $1.07 \mathrm{~b}$ & $1.07 \mathrm{~b}$ & $1.07 \mathrm{a}$ \\
$\mathrm{CV}(\%)$ & 2.64 & 1.62 & 2.10 & 3.40 \\
LSD $_{0.05}$ & 0.0027 & 0.0017 & 0.0021 & 0.0037 \\
Level of & $* *$ & $* *$ & $* *$ & $* *$ \\
significance & & & &
\end{tabular}

Numbers in columns followed by the same letter are not statistically different at $\mathrm{P}_{0.05}$.

$* *=$ Significant at $1 \%$ level of probability. $\mathrm{V}_{1}-$ BARI TPS $-1, \mathrm{~V}_{2}-$ Lady Rosetta, $\mathrm{V}_{3}-$ Asterix, $\mathrm{V}_{4}-$ Courage

Significant variation was found among different levels of vermicompost on specific gravity of tuber at different ambient storage time. At 0 DAS highest specific gravity of tuber was exhibited by $\mathrm{M}_{3}$ (1.075) and lowest was exhibited by $\mathrm{M}_{1}$ (1.068) which is statistically similar to $\mathrm{M}_{2}$. At 20 DAS highest specific gravity of tuber was exhibited by $M_{4}$ (1.072) and lowest was exhibited by $M_{1}$ (1.064) which was statistically similar to $\mathrm{M}_{2}$. At 40 DAS highest specific gravity of tuber was exhibited by $\mathrm{M}_{4}$ (1.071) and lowest was exhibited by $\mathrm{M}_{1}$ (1.061) which was statistically similar to $\mathrm{M}_{2}$. At 60 DAS highest specific gravity of tuber was exhibited by $\mathrm{M}_{4}$ (1.066) which was statistically similar to $\mathrm{M}_{3}$ and lowest was exhibited by $\mathrm{M}_{1}$ (1.058) which was also statistically similar to $\mathrm{M}_{2}$ (Table 4 ).

Table 4. Effect of vermicompost on specific gravity at different days after storage of potato tuber

\begin{tabular}{c|c|c|c|c}
\hline \multirow{2}{*}{ Vermicompost level } & \multicolumn{4}{|c}{ Specific gravity $\left(\mathrm{g} \mathrm{cm}^{-3}\right)$} \\
\cline { 2 - 5 } & 0DAS & 20DAS & $40 \mathrm{DAS}$ & $60 \mathrm{DAS}$ \\
\hline $\mathrm{M}_{1}$ & $1.068 \mathrm{c}$ & $1.064 \mathrm{c}$ & $1.061 \mathrm{c}$ & $1.058 \mathrm{~b}$ \\
$\mathrm{M}_{2}$ & $1.070 \mathrm{c}$ & $1.065 \mathrm{c}$ & $1.062 \mathrm{c}$ & $1.059 \mathrm{~b}$ \\
$\mathrm{M}_{3}$ & $1.075 \mathrm{~b}$ & $1.070 \mathrm{~b}$ & $1.067 \mathrm{~b}$ & $1.065 \mathrm{a}$ \\
$\mathrm{M}_{4}$ & $1.078 \mathrm{a}$ & $1.072 \mathrm{a}$ & $1.071 \mathrm{a}$ & $1.066 \mathrm{a}$ \\
$\mathrm{CV}(\%)$ & 2.47 & 1.87 & 2.30 & 3.12 \\
LSD $_{0.05}$ & 0.0022 & 0.0017 & 0.0020 & 0.0028 \\
Level of significance & $* *$ & $* *$ & $* *$ & $* *$ \\
\hline
\end{tabular}

Numbers in columns followed by the same letter are not statistically different at $\mathrm{P}_{0.05}$. ** = Significant at $1 \%$ level of probability. $\mathrm{M}_{1}-0 \mathrm{tha}^{-1}$ (Control), $\mathrm{M}_{2}-2 \mathrm{t} \mathrm{t} \mathrm{ha-1}, \mathrm{M}_{3}-4 \mathrm{t} \mathrm{tha}{ }^{-1}, \mathrm{M}_{4}-6 \mathrm{t} \mathrm{ha}^{-1}$ 
No significant variation was found among different variety and vermicompost levels on specific gravity of tuber at 0 DAS. At 20 DAS maximum specific gravity of tuber exhibited by $\mathrm{V}_{3} \mathrm{M}_{4}$ (1.090) and minimum was exhibited by $\mathrm{V}_{1} \mathrm{M}_{3}$ (1.046). At 40 DAS maximum specific gravity of tuber exhibited by $\mathrm{V}_{3} \mathrm{M}_{4}$ (1.088) and minimum was exhibited by $\mathrm{V}_{1} \mathrm{M}_{2}$ (1.041) which was statistically similar to $\mathrm{V}_{1} \mathrm{M}_{1}$ and $\mathrm{V}_{1} \mathrm{M}_{3}$. At 60 DAS maximum specific gravity of tuber exhibited by $\mathrm{V}_{3} \mathrm{M}_{4}$ (1.085) which was statistically similar to $\mathrm{V}_{3} \mathrm{M}_{3}$ and $\mathrm{V}_{4} \mathrm{M}_{4}$; minimum was exhibited by $\mathrm{V}_{1} \mathrm{M}_{1}$ (1.041) (Table 5).

Table 5. Combined effect of variety and vermicompost on specific gravity at different days after storage of potato tuber

\begin{tabular}{c|c|c|c|c}
\hline \multirow{2}{*}{ Combination } & \multicolumn{4}{|c}{ Specific gravity $\left(\mathrm{g} \mathrm{cm}^{-3}\right)$} \\
\cline { 2 - 5 } & 0 DAS & $20 \mathrm{DAS}$ & $40 \mathrm{DAS}$ & $60 \mathrm{DAS}$ \\
\hline $\mathrm{V}_{1} \mathrm{M}_{1}$ & 1.049 & $1.047 \mathrm{~g}$ & $1.042 \mathrm{~h}$ & $1.041 \mathrm{~h}$ \\
$\mathrm{~V}_{1} \mathrm{M}_{2}$ & 1.050 & $1.042 \mathrm{i}$ & $1.041 \mathrm{~h}$ & $1.035 \mathrm{ij}$ \\
$\mathrm{V}_{1} \mathrm{M}_{3}$ & 1.052 & $1.046 \mathrm{gh}$ & $1.041 \mathrm{~h}$ & $1.038 \mathrm{hi}$ \\
$\mathrm{V}_{1} \mathrm{M}_{4}$ & 1.055 & $1.043 \mathrm{hi}$ & $1.047 \mathrm{~g}$ & $1.032 \mathrm{j}$ \\
$\mathrm{V}_{2} \mathrm{M}_{1}$ & 1.064 & $1.059 \mathrm{f}$ & $1.057 \mathrm{f}$ & $1.054 \mathrm{~g}$ \\
$\mathrm{~V}_{2} \mathrm{M}_{2}$ & 1.066 & $1.062 \mathrm{f}$ & $1.060 \mathrm{f}$ & $1.058 \mathrm{fg}$ \\
$\mathrm{V}_{2} \mathrm{M}_{3}$ & 1.071 & $1.067 \mathrm{e}$ & $1.065 \mathrm{e}$ & $1.063 \mathrm{ef}$ \\
$\mathrm{V}_{2} \mathrm{M}_{4}$ & 1.072 & $1.068 \mathrm{e}$ & $1.067 \mathrm{e}$ & $1.065 \mathrm{de}$ \\
$\mathrm{V}_{3} \mathrm{M}_{1}$ & 1.080 & $1.078 \mathrm{c}$ & $1.075 \mathrm{~cd}$ & $1.071 \mathrm{~cd}$ \\
$\mathrm{~V}_{3} \mathrm{M}_{2}$ & 1.081 & $1.078 \mathrm{c}$ & $1.075 \mathrm{~cd}$ & $1.071 \mathrm{~cd}$ \\
$\mathrm{~V}_{3} \mathrm{M}_{3}$ & 1.091 & $1.086 \mathrm{~b}$ & $1.083 \mathrm{~b}$ & $1.082 \mathrm{a}$ \\
$\mathrm{V}_{3} \mathrm{M}_{4}$ & 1.094 & $1.090 \mathrm{a}$ & $1.088 \mathrm{a}$ & $1.085 \mathrm{a}$ \\
$\mathrm{V}_{4} \mathrm{M}_{1}$ & 1.077 & $1.073 \mathrm{~d}$ & $1.069 \mathrm{e}$ & $1.066 \mathrm{de}$ \\
$\mathrm{V}_{4} \mathrm{M}_{2}$ & 1.081 & $1.077 \mathrm{c}$ & $1.073 \mathrm{~d}$ & $1.070 \mathrm{~d}$ \\
$\mathrm{~V}_{4} \mathrm{M}_{3}$ & 1.084 & $1.080 \mathrm{c}$ & $1.078 \mathrm{c}$ & $1.076 \mathrm{bc}$ \\
$\mathrm{V}_{4} \mathrm{M}_{4}$ & 1.089 & $1.086 \mathrm{~b}$ & $1.082 \mathrm{~b}$ & $1.081 \mathrm{ab}$ \\
$\mathrm{CV} \%)$ & 2.47 & 1.87 & 2.30 & 3.12 \\
$\mathrm{LSD}_{0.05}$ & - & 0.003 & 0.003 & 0.005 \\
Level of $_{\text {significance }}$ & $\mathrm{NS}$ & $* *$ & $* *$ & $* *$ \\
\hline
\end{tabular}

Numbers in columns followed by the same letter are not statistically different at $\mathrm{P}_{0.05}$.

$* *=$ Significant at $1 \%$ level of probability, NS = Not significant. $\mathrm{V}_{1}-\mathrm{BARI}$ TPS $-1, \mathrm{~V}_{2}-$ Lady Rosetta, $\mathrm{V}_{3}-$ Asterix, $\mathrm{V}_{4}-$ Courage; $\mathrm{M}_{1}-0 \mathrm{tha} \mathrm{C}^{-1}$ (Control), $\mathrm{M}_{2}-2 \mathrm{tha}{ }^{-1}, \mathrm{M}_{3}-4 \mathrm{t} \mathrm{ha}^{-1}, \mathrm{M}_{4}-6 \mathrm{tha}^{-1}$ 
There was an overall reduction in specific gravity with the increase in storage time and variation was found among different genotypes (Asmamaw et al., 2010). Vermicompost had a great effect on increasing specific gravity of potato tubers. With the increasing of Vermicompost levels were shown maximum specific gravity in tuber (Agrawal et al., 2017).

\section{CONCLUSION}

From the study, it can be concluded that the variety and vermicompost have shown the statistically significant variation among the parameters studied under the experiment. Based on storage and processing parameters, it can be said that $\mathrm{V}_{3}$ : BARI Alu-25 (Asterix) has shown better performance on most of the varieties and $\mathrm{M}_{4}$ : $6 \mathrm{t} \mathrm{ha}^{-1}$ has shown a significantly better result on most of the vermicompost levels. The potato growers of Bangladesh may apply vermicompost on their field at the rate of $6 \mathrm{t} \mathrm{ha}^{-1}$ for better processing quality in combination with potato varieties Lady Rosetta and Asterix.

\section{ACKNOWLEDGMENT}

The authors thankfully acknowledged the Ministry of Education, Government of the People's Republic of Bangladesh for supporting to conduct the present study.

\section{Conflict of interest}

The authors declare that there is no conflict of interest with this research.

\section{REFERENCE}

Agrawal, S., Lekhi, R. and Patidar, P. (2017). Effect of Different Level of Potassium and Vermicompost on Tuber Quality of Potato (Solanum tuberosum L.) and Storage. International Journal of Current Microbiology and Applied Sciences, 6(11): 29782983.

Amoros, W., Espinoza, J. and Bonierbale, M. (2000). Assessment of variability for processing potential in advanced potato populations. CIP, Lima.

Asmamaw, Y., Tekalign, T. and Workneh, T.S. (2010). Specific Gravity, Dry Matter Concentration, $\mathrm{pH}$, and Crisp-making Potential of Ethiopian Potato (Solanum tuberosum L.) Cultivars as Influenced by Growing Environment and Length of Storage Under Ambient Conditions. Potato Research, 53(2): 95-109.

Barton, W.G. and Longman, W. (1989). The potato. Scientific and Technical. 3rd edition, USA press, California, USA. p. 599-601.

Basker, D. (1975). Centigrade scale temperature corrections to the specifie gravity of potatoes. Potato Research, 18(1): 123-125.

BBS (Bangladesh Bureau of Statistics) (2013). Monthly statistical year book. Ministry of Planning, Government of the People's Republic of Bangladesh. p. 64.

Burton, W.G., van Es, A. and Hartmans, K.J. (1992). The physics and physiology of storage. In: The potato crop, Harris, P. M. (ed.). Chapman and Hall, London, p. 608-727. 
Capezio, S.B. (1987). Specific gravity variability in first clonal generation in potato. Balance, BS. As. (Argentina) p. 37.

Cronk, T.C., Kuhn, G.O. and McArdle, F.J. (1974). The influence of stage of maturity level of nitrogen fertilization and storage on the concentration of solanine in tubers of three potato cultivars. Bulletin of Environmental Contamination and Toxicology, 11(2): 163168.

FAOSTAT (Food and Agriculture Organization of the United Nations). (2017). Crop production Statistical Database. Retrieved on July 16, 2018. $<$ http://www.fao.org/faostat/en/\#data>

Gomez, K.A. and Gomez, A.A. (1984). Statistical procedure for agricultural research. 2nd Edition. John Willey and Sons, New York, USA. 139-180.

Kabira, J.N. and Lemaga, B. (2006). Potato Processing: Quality Evaluation procedures for research and food industries applications in East and Central Africa. Kenya Agricultural Research Institute, Nairobi, Kenya. p. 12.

Keijbets, M.J.H. (2008). Potato processing for the consumer: Developments and future challenges. Potato Research, 51(3-4): 271-281.

Kmet'ová, M., Kováčik, P. and Renčo, M. (2013). The effect of different doses application of dry granulated vermicompost on yield parameters of maize and potatoes. Actafytotechnica et zootechnica. 16(1).

Linnemann, A.R., van Es, A. and Hartmans, K.J. (1985). Changes in content of L-ascorbic acid, glucose, fructose, sucrose and total glykoalkaloids in potatoes (cv. Bintje) stored at 7, 16, and $28^{\circ} \mathrm{C}$. Potato Research, 28(3): 271-278.

Maga, J.A. and Fitzpatrick, T.J. (1980). Potato glycoalkaloids. C R C Critical Reviews in Food Science and Nutrition. Informa UK Limited. 12(4): 371-405.

Metrological Centre, Climate Division, Agargaon, Dhaka, Bangladesh. Retrieved on May13, 2017 from http://www.bmd.gov.bd/

Miller, R.A., Harrington, J.D. and Kuhn, G.D. (1975). Effect of variety and harvest date on tuber sugars and chip color. American Potato Journal, 52(12): 379-386.

Mondal, M.R.I., Islam, M.S., Jalil, M.A.B., Rahman, M.M., Alam, M.S. and Rahman, M.H.H. (2011). KrishiProjuktiHatboi (Handbook of Agro-technology), 5th edition. Bangladesh Agricultural Research Institute, Gazipur-1701, Bangladesh, p. 307.

Mostofa, M., Roy, T.S., Chakraborty, R., Modak, S., Kundu, P.K., Zaman, M.S., Rahman, M. and Shamsuzzoha, M. (2019). Effect of Vermicompost and Tuber Size on Processing Quality of Potato during Ambient Storage Condition. International Journal of Plant \& Soil Science, 26(3): 1-18.

Salisbury, F.B. and Ross, C.W. (1992). Plant physiology. 4th ed. Wadsworth, Belmont. California, USA. P. 57-63.

Senapati, B.K. (1992). Vermitechnology: an option for recycling cellulosic waste in India. In: New Trends in Biotechnology. Oxford and IBH Publications Pvt. Co. Ltd. Calcutta. p. 347-358.

Senesi, N., Miano, T.M. and Brunetti, G. (1996). Humic-like Substances in Organic Amendments and Effects on Native Soil Humic Substances. In: Humic Substances in Terrestrial Ecosystems, Piccolo, A. (ed.). Elsevier, New York. 531-593. 
Singh, M. (2010). Projection of potato export from India: a markov chain approach. Potato Journal, 37, 18-55.

Statistix, R. (2013).Statistix 10 Analytical Software. Tallahassee, FL USA.

Suyre, M., Khan, R.U., Fridi, S.R., Inmad, M. and Mehjarin, B. (1975). Preparation and quality evaluation of potato ready to drink beverage. ARPN Journal of Agricultural and Biological Science, (8): 27-33.

Tai, G.C.C. and Coleman, W.K. (1999). Genotype $\times$ environment interaction of potato chip colour. Canadian Journal of Plant Science, 79(3): 433-438. 